\title{
Change in acetylcholine activity and some blood parameters in adult sheep dipped in deltamethrin
}

\author{
A.S. Ahmed \\ Medical laboratories Department, Technical College, Northern Technical University, Kirkuk, Iraq
}

\author{
Article information \\ Article history: \\ Received March 16, 2020 \\ Accepted April 22, 2020 \\ Available online February 22, 2021

\section{Keywords:} \\ Acetylcholine \\ Deltamethrin \\ Acetylcholine esterase activity \\ Sheep \\ Blood parameters \\ Correspondence: \\ A.S. Ahmed \\ aydinfedakar@ntu.edu.iq
}

\begin{abstract}
The aim of this was to elucidate the effects of deltamethrin dipping on acetylcholine activity in serum and some blood parameters of sheep. The study was conducted on forty adult sheep dipped in deltamethrin in concentration of 1:1000L of water. Venous blood samples were collected from each animal before and after dipped. There was significant inhibition in the acetylcholine esterase in all subjected animals after dipping. Mean values of hematological investigations showed a significant rise in the number of total leucocytes (leukocytosis) with significant decline in hemoglobin concentration and Red cell indices in all dipped animals after dipping in deltamethrin when compared with mean values obtained from the same animals before dipping. Conclusion of our results revealed that poisoning with deltamethrin affects blood parameters through the inhibition of acetylcholine esterase.
\end{abstract}

DOI: 10.33899/ijvs.2020.126813.1385, (02021, College of Veterinary Medicine, University of Mosul. This is an open access article under the CC BY 4.0 license (http://creativecommons.org/licenses/by/4.0/).

\section{Introduction}

Organophosphorus compound and carbamate pesticides are broadly used in public health (1), veterinary practice, and in agriculture (2). They pose main environmental pollution complications and health threats to people and animals $(3,4)$. These pesticides inhibit cholinesterase (ChE) activity in the nervous tissues and neuromuscular junctions, causing an accumulation of acetylcholine at the nerve endings which afterward produces signs of toxicosis characterized by nicotinic, muscarinic, and central nervous system effects $(5,6)$. The Cholinesterase activities in blood, tissue and brain can be easily measured $(7,8)$ and their investigations are useful in determining the exposure status of cholinesterase inhibitors and detecting the toxicity of these compounds (810). Acetylcholinesterase activity inhibition have been widely studied red blood cells, plasma and tissues in workers $(11,12)$, experimental animals $(13,14)$, fish $(9)$, birds $(15,16)$ and in farm animals $(8,17)$ after exposure to organophosphate and carbamate pesticides but rarely studied in serum (18) specially in our country and adverse effect on blood parameters. One of the basic mechanisms of the harmfulness of the pesticides seems to be lipid peroxidation; as a consequence, these composites can lead to some blood cells disorders (19). So this study was designed to elucidate the effects of deltamethrin on acetylcholine and some blood parameters of sheep dipped in deltamethrin.

\section{Material and methods}

\section{Sample collection}

This study was conducted on forty adult sheep dipped in pesticides. Venous blood samples were collected from each animal; one before dipping (used as control, and the second sample collected after dipping, then each sample was divided into two parts; first part used for complete blood pictures study and the remainder was centrifuged, after clotting, at 2000-3000 rpm for 20 minutes, and the separated serum was immediately frozen at $-20^{\circ} \mathrm{C}$ for later estimation of Ach esterase activity. 


\section{Methods}

Blood parameters red blood cells (RBC) count, white blood cells (WBC) count, differential leucocyte count, hematocrit, hemoglobin concentration, red cell indices estimated by automated machine (Ruby- automated hematology analyzer) (20). Acetyl choline esterase assayed quantitatively in vitro by using the enzyme linked immunosorbent assay (ELISA) kit (RelAssay Diagnostics) based on the principle of biotin double antibody sandwich technology.

\section{Dipping}

Animals were stopped giving water for 12 hours. One hour prior to dipping they were allowed one hour for taking water. Then All subjected animals were dipped in a basin, $0.9 * 1.5 * 3 \mathrm{~m}$ in dimension, containing deltamethrin $25 \mathrm{~g} / \mathrm{L}$ (DELTDIP ${ }^{\circledR}$ ) in concentration 1:1000L for 30 seconds.

\section{Statistical analysis}

Data obtained were analyzed using the Excel program version 10 package. The significance of invariant differences was assessed by student's t- tests and all values were twosided. A $\mathrm{P}<0.01$ was considered statistically significant.

\section{Results}

There was significant decrease in the acetylcholine esterase activity in all subjected animals after dipping as compared to pre-dipping period (Figure 1). The mean values were 5.74 and $1.24 \pm 0.31 \mathrm{nmol} / \mathrm{Ml}$ before and after dipping respectively.

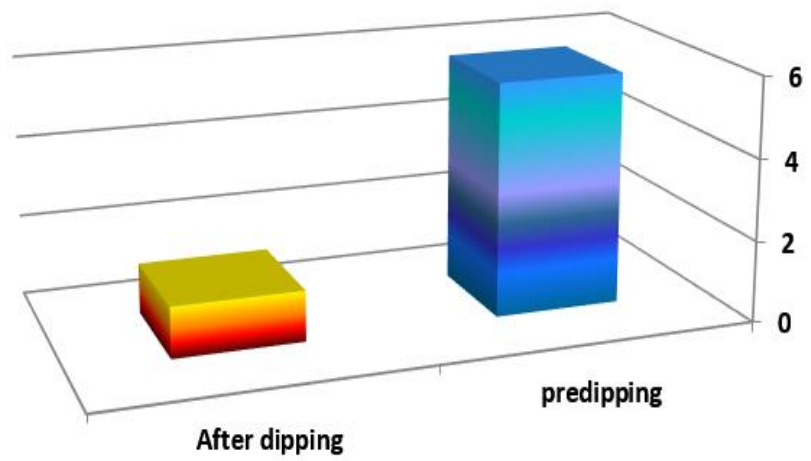

Figure 1: Mean values \pm SD of Acetylcholine esterase activities in dipped sheep before -and- after dipping in deltamethrin.

Mean values of hematological investigations showed a significant rise in the number of total leucocytes with significant decline in hemoglobin concentration in all animals after dipping in pesticides when compared with mean values obtained from the same animals before dipping (table1). Regarding the differential leucocyte count, our result showed significant increase in the granular (neutrophils and eosinophils) and some granular leucocytes (lymphocytes and monocytes). Mean values of Red cell indices; Mean corpuscular volume (MCV), mean corpuscular hemoglobin $(\mathrm{MCH})$ and Mean corpuscular hemoglobin concentration (MCHC), also showed significant decrease. There was a decrease in the mean value of red blood cells (RBCs) count and hematocrit (Hct) but was statistically no significant.

Table 1: Mean values \pm SD of blood parameters in dipped sheep before -and- after dipping in deltamethrin

\begin{tabular}{|c|c|c|c|c|c|c|c|c|c|c|c|}
\hline & $\begin{array}{c}\text { WBC } \\
10^{6} / \mathrm{m}^{3}\end{array}$ & $\begin{array}{c}\text { LYM } \\
\%\end{array}$ & $\begin{array}{c}\text { MON } \\
\%\end{array}$ & $\begin{array}{c}\text { NEU } \\
\%\end{array}$ & $\begin{array}{c}\text { EOS } \\
\%\end{array}$ & $\begin{array}{l}\mathrm{RBC} \\
\mathrm{m} / \mathrm{m}^{3}\end{array}$ & $\begin{array}{c}\text { MCV } \\
\text { (fl) }\end{array}$ & $\begin{array}{l}\text { Hct } \\
(\%)\end{array}$ & $\begin{array}{c}\mathrm{MCH} \\
(\mathrm{pg})\end{array}$ & $\begin{array}{c}\mathrm{MCHC} \\
(\mathrm{g} / \mathrm{dL})\end{array}$ & $\begin{array}{c}\mathrm{HB} \\
(\mathrm{g} / \mathrm{dL})\end{array}$ \\
\hline Before & 13.40 & 44.06 & 13.1 & 23.15 & 0.26 & 4.0 & 32.49 & 27.86 & 23.76 & 80.99 & 10.3 \\
\hline dipping & \pm 1.30 & \pm 1.06 & \pm 1.25 & \pm 0.7 & \pm 0.03 & \pm 0.37 & \pm 0.8 & \pm 0.83 & \pm 0.82 & \pm 1.23 & \pm 0.38 \\
\hline dipping & \pm 1.8 & \pm 1.86 & \pm 1.63 & \pm 0.93 & \pm 0.07 & \pm 0.36 & \pm 28.46 & \pm 0.53 & \pm 1.04 & \pm 0.71 & \pm 0.34 \\
\hline
\end{tabular}

$* \mathrm{P}<0.01$ statistically significant.

\section{Discussion}

Organophosphorus compounds (OP) is progressively increasing in Iraq, most likely because of the comprehensive availability of pesticides as a result of wide-ranging use in agriculture, veterinary and also because of over the counter sale of these items. Current results showed a significant decrease in acetylcholine activities in the sera of sheep after dipping in pesticides when compared with the values obtained after dipping. This conclusion confirms the effect of these compounds on acetylcholine activity and put forward that estimation of serum choline esterase is useful in conformation of $\mathrm{OP}$ poisoning. The reported results are similar to the recorded results in other studies (21). When acetylcholine esterase is inactivated, it leads accumulation of acetylcholine throughout the nervous system and causes hyperstimulation of muscarinic and nicotinic receptors (22).

Accumulation of free radicals resulted from acetylcholine esterase activity inhibition leads to lipid peroxidation (23). Free radicals contribute in toxicity of pesticides which may persuade oxidative stress resulting in releasing of free radicals and modification in antioxidants or oxygen free radical scavenging enzyme system (24). In a study, Handekari et al. (19), reported that cells constantly 
suffer from oxidative stress in spite of over activity of antioxidant defense mechanism indicated by increase in erythrocyte. Increase in antioxidant enzymes levels may be essential to purify increased concentration of lipid peroxidation yields that are oxidative stress products because of organophosphorus poisoning (23).

The significant increase in leucocytes observed after dipping in pesticides implies the activation of the defense mechanism and immunity. The same observation was reported by Hundekari (19) that the number of white blood cell count was increased significantly in all cases of OP poisoning. They also detected increased in total white blood cells with mild decrease in neutrophils count as compared to control values. In acute OP toxicity, overproduction of reactive $\mathrm{O}_{2}$ species immediately results in major lipid peroxidation. The liability of erythrocytes and leucocytes especially lymphocytes to oxidative stress due to exposure to the pesticide is a function of overall equilibrium between degree of oxidative stress and antioxidant protection proficiency. Thus the antioxidant attack aptitude of exposed subjects may alter directly or indirectly by OP compounds and therefore affect their liability to oxidative stress of exposed subjects and consequently affect their vulnerability to oxidative stress (24).

There is significant decline in the mean values of hemoglobin concentration of animals after dipping compared to the mean values before dipping, possibly due to the decline in formation of hemoglobin or may be due to binding of organophosphorus insecticides on iron, followed by a lack of fusion of iron with hemoglobin leading to low $\mathrm{MCV}$, i.e. decreased size of erythrocytes (microcytosis).

\section{Conclusion}

From the above results it was concluded that organophosphorus compounds cause a significant decline in AChE activity and the severity of poisoning aids in predicting OP poisoning and effects on blood parameters. These effects may be through oxidative damage caused by elevating lipid peroxide levels.

\section{Acknowledgements}

Special thanks to Assistant Professor Dr. Abdulmuneim Al-Jubori, Dr Nebeel Rasheed and Dr. Othman Mustafa for their helps in dipping of sheep and collection of blood samples. Also I would like to thank Dr. Zaid Al-bayati for his help in ELISA technique.

\section{Conflict of interest}

The authors declare that there are no conflicts of interest regarding the publication of this manuscript.

\section{References}

1. Jaga K, Dhamani C. Sources of exposure to and public health implications of organophosphate pesticides. Rev Panam Salud Publica. 2003;14:171-185. DOI:10.1590/s1020-49892003000800004

2. Coggon D. Work with pesticides and organophosphate sheep dips. Occup Med. 2002;52:467-470. DOI:10.1093/occmed/52.8.467

3. Wilson BW. Clinical enzymology. In: Loeb WF, Quimby FW. The clinical chemistry of laboratory animals. Taylor and Francis, Philadephia, PA, USA. 1999:399-454. ISBN 9781420091137

4. Sadiq SA, Jarjees MT. The histological and histochemical changes in the kidney of rabbit induced by diazinon. Iraqi $\mathrm{J}$ Vet Sci. 2019;32(2):303-308. doi:10.33899/ijvs.2019.153868

5. Wilson BW, Arrieta DE, Henderson JD. Monitoring cholinesterases to detect pesticide exposure. Chemico Biolog Inter. 2005;157-158:253256. DOI:10.1016/j.cbi.2005.10.043

6. Kwong TC. Organophosphate pesticides: Biochemistry and clinical toxicology. Therap Drug Mon. 2002;24:144-149. DOI: $10.1097 / 00007691-200202000-00022$

7. Alias, A.S. Electrometric method determination of blood cholinesterase activity in stray dogs. Iraqi J Vet Sci. 2014;28(2):153-159. doi:10.33899/ijvs.2014.116934.

8. Mohammad FK, Al-Zubaidy MH, Alias AS. Electrometric determination of erythrocyte, plasma and whole blood cholinesterase activities in sheep, goats and cattle and their in vitro inhibition by anticholinesterase insecticides. J Pharmacol Toxicol. 2007;2:131-141. DOI:10.3923/jpt.2007.131.141

9. Choi JY. Acetylthiocholine (ATC) cleaving cholinesterase (ChE) activity as a potential biomarker of pesticide exposure in the Manila clam, Ruditapes philippinarum, of Korea. Marine Environ Res. 2011;71:162-168. DOI:10.1016/j.marenvres.2010.12.007

10. Khalil AK, Abbas KS. The Measurements of the Cholinesterase activity of brain and plasma in rabbits by using modified michel and ellman assays. Insights Enzy Res. 2017;192:9. DOI:10.21767/25734466.100009

11. Ahmad AS. Evaluation of acetylecholine esterase activity in the blood of workers exposed to organophosphate and carbamate insecticides by an electrometric method. Kirkuk J Sci Stud. 2013;3(3):26-33.

12. Ahmed OA, Mohammad FK. Electrometric determination of blood cholinesterase activities in workers exposed to insecticides in Mosul, Iraq. J Environ Toxicol. 2007;1:144-148. DOI:10.3923/rjet.2007.144.148

13. Acker CI. Repeated malathion exposure induces behavioral impairment and AChE activity inhibition in brains of rat pups. Ecotoxicol Environ Safe. 2011;74(8):2310-2315. DOI:10.1016/j.ecoenv.2011.07.035

14. Roszczenko A, Rogalska J, Moniuszko JJ, Brzóska MM. The effect of exposure to chlorfenvinphos on lipid metabolism and apoptotic and necrotic cells death in the brain of rats. Exp Toxicol Pathol. 2012;65(5):531-539. DOI:10.1016/j.etp.2012.03.002

15. Faris GA. A Survey of the natural cholinesterase activity in some animals and birds of Mosul City. J. Res Lep. 2019;50(4):377-381. DOI:10.36872/LEPI/V50I4/201101

16. Alias AS, Al-Zubaidy MH, Mousa YJ, Mohammad FK. Plasma and whole brain cholinesterase activities in three wild bird species in Mosul, IRAQ: In vitro inhibition by insecticides. Interdiscip Toxicol. 2011;4(3):144-148. doi:10.2478/v10102-011-0022-x

17. Mohammad F, Al-Baggou BK, Alias AS, Faris GA. Application of an electrometric method for measurement of in vitro inhibition of blood cholinesterases from sheep, goats and cattle by dichlorvos and carbaryl. Vet Med Praha. 2006;51:45.

18. Omidpanah N, Jalilian N, Vaisi RA, Sadeghi M, Mozaffari H. Evaluation of butyrylcholinesterase and acetylcholinesterase activity in serum and saliva of myocardial infarction patients. Biomed Res Therap. 2018;5(10):2762-2767.

19. Hundekari IA, Suryakar AN, Rathi DB. Acute organo-phosphorus pesticide poisoning in North Karnataka, India:oxidative damage, haemoglobin level and total leukocyte. Afr Health Scis. 2013;13(1):129-136. doi:10.4314/ahs.v13i1.18 . 
20. Madreseh G. S, Samani, A.D. Evaluation of performance rate, some hematological and biochemical parameters in Iranian Afshari breed fattened sheep fed diet containing Gundelia (Gundelia tournefortii L.)Iraqi $J \quad$ Vet $\quad$ Sci,2019, $33 \quad$ (1): 3338.DOI: $10.33899 /$ ijvs.2019.125515.1037

21. Karalliedde L, Edwards P, Marrs T. Variables influencing the toxicity of organophosphates in humans. Food Chem Toxicol. 2003;41:1-13. DOI:10.1016/s0278-6915(02)00232-6

22. Reiner E, Radic Z, Vera S. Mechanisms of organophosphorus toxicity and detoxification with emphasis on studies in Croatia. Arh Hig Rada Toksikol. 2007;58:329-338. DOI:10.2478/v10004-007-0026-2

23. Akhgari M, Abdollahi M, Kebryaeezadeh A, Hosseini R, Sabzevari O. Biochemical evidence for free radical induced lipid peroxidation as a mechanism for subchronic toxicity of malathion in blood and liver of rats. Hum Exp Toxicol 2003;22:205-211. DOI:10.1191/0960327103ht346oa

24. Banerjee BD, Seth V, Bhattacharya A, Pasha ST, Chakraborty AK. Biochemical effects of some pesticides on lipid peroxidation and free radical scavengers. Toxicol Lett. 1999;107:33-47. DOI:10.1016/s0378$\underline{4274(99) 00029-6}$

\section{التغير في نشاط الأسيتيل كولين وبعض معايير الام في الأغنام المغطسة في مبيد دلتاميثيرين \\ آيدن صديق أحمد}

قسم المختبرات الطبية، الكلية التقنية، الجامعة التقنية الشمالية، كركوك،

الخلاصة

هدف الدراسة هو توضيح تأثير مركب الفسفور العضوي المستخدم

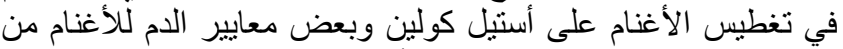

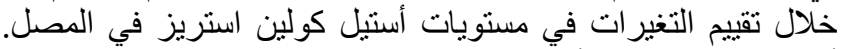

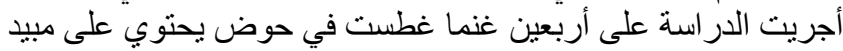

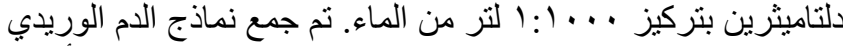

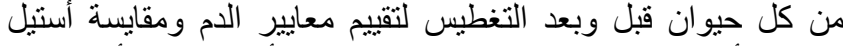

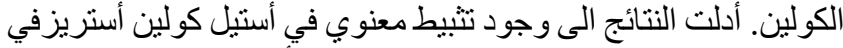

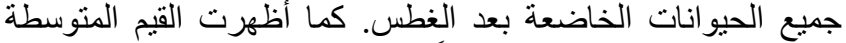

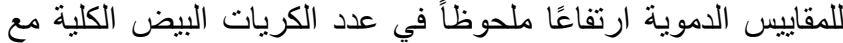
انخفاض معنوي في تركيز الهيمو غلوبين ومؤشرات الخلية الحمر اء في في

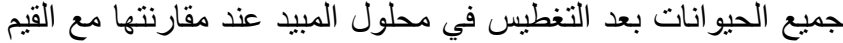
التي تم الحصول عليها من نفس الحيوانات قبل الغطس. كثفت النفات النتائج

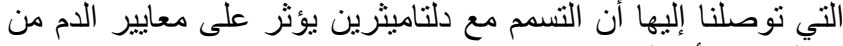
خلال نثبيط أستيل استريز. 